\title{
SYNTHESIS AND CHARACTERIZATION OF A NEW BITHIAZOLE-CONTAINING CONJUGATED POLYMER AND ITS THERMAL DECOMPOSITION KINETICS
}

\author{
Adnan Kurt ${ }^{1, *}$, Hacer Andan ${ }^{1}$, Murat Koca ${ }^{2}$ \\ ${ }^{1}$ Department of Chemistry, Faculty of Science and Arts, Adiyaman University, Adiyaman, Turkey \\ ${ }^{2}$ Department of Pharm. Chemistry, Pharmacy Faculty, Adiyaman University, Adiyaman, Turkey \\ akurt@adiyaman.edu.tr
}

\begin{abstract}
A new conjugated polymer containing a bithiazole group is prepared by the polycondensation of 2,2'-diamino-4,4'-bithiazole and terephthaldialdehyde in the presence of glacial acetic acid. The kinetics of thermal degradation of the new polymer are investigated by thermogravimetric analysis at different heating rates. The temperature corresponding to the maximum rate loss shifts to higher temperatures with increasing heating rate. The thermal decomposition activation energies of the conjugated polymer in a conversion range of 3-15\% are 288.4 and $281.1 \mathrm{~kJ} / \mathrm{mol}$ by the Flynn-Wall-Ozawa and Kissinger methods, respectively. The Horowitz-Metzger method shows that the thermodegradation mechanism of the conjugated polymer proceeds over a three-dimensional diffusion type deceleration $\mathrm{D}_{3}$ mechanism. The optimum heating rate is $20^{\circ} \mathrm{C} / \mathrm{min}$.
\end{abstract}

Keywords: bithiazole ring; conjugated polymer; synthesis and characterization; thermal decomposition kinetics; activation energy

\section{СИНТЕЗА И КАРАКТЕРИЗАЦИЈА НА НОВ БИТИАЗОЛСКИ КОНЈУГИРАН ПОЛИМЕР И КИНЕТИКА НА НЕГОВО РАЗЛОЖУВАЊЕ}

\begin{abstract}
Приготвен е нов конјугиран полимер што содржи битиазол со поликондензација на 2,2'диамино-4,4'-битиазол и терефталдиалдехид во присуство на глацијална оцетна киселина. Беше испитана кинетиката и термичкото разложување на новиот полимер со термогравиметриска анализа при различни брзини на загревање. Температурата што одговара на максималната брзина се поместува кон повисоки температури со зголемување на брзината на загревање. Според методите на Flynn-Wall-Ozawa и на Kissinger, активациската енергија на термичкото разложување на конјугираниот полимер во опсегот на претворба од 3 до 15 \% изнесува, соодветно, 288,4 и 281,1 $\mathrm{kJ} / \mathrm{mol}$. Методот на Horowitz-Metzger покажува дека термодеградацискиот механизам на конјугираниот полимер се одвива преку тридимензионален забавувачки $\mathrm{D}_{3}$ механизам. Оптималната брзина на загревање изнесува $20^{\circ} \mathrm{C} / \mathrm{min}$.
\end{abstract}

Клучни зборови: битиазолски прстен; конјугиран полимер; синтеза и карактеризација; кинетика на термичко разложување; активациска енергија

\section{INTRODUCTION}

Polymers represent a unique class of materials as a result of their distinctive properties. A plethora of polymers with different functional groups and chemical structures suitable for specific applications have been synthesized and used in many technological platforms. Among these, a class of polymers that are particularly important for optoelectronic applications are $\pi$-conjugated polymers [1]. Aromatic poly(Schiff bases) are amongst the main members of these conjugated polymers. In addition to the advantages of these polymers, such as easy availability and a large number of monomer sources, they coordinate with different metal ions and are thus suitable for the 
preparation of high performance materials in terms of electrical, optical, magnetic and thermal properties $[2,3]$.

In particular, an important group of compounds used in the synthesis of $\pi$-conjugated aromatic poly(Schiff bases) by the polycondensation reaction method are bithiazoles. Some studies on the preparation of bithiazole-based polymers have been reported in recent years [2]. For example, Weng et al. [4] synthesized a new 2,2'-diamino4,4'-bithiazole polymer containing salicylic acid and then prepared complexes of this polymer with iron and Prussian blue and investigated their magnetic properties in detail. In another study, Sun et $a l$. [5] succeeded in the synthesis and characterization of a new heterocyclic polymer incorporating both bithiazole and tetrathiapentalene moieties in the main chain. The magnetic properties of these synthesized metallopolymers were measured as a function of magnetic field strength and temperature under an applied magnetic field. Deng et al. [6] synthesized a new bithiazole-containing diphenol derivative as a result of the reaction of the 4hydroxybenzaldehyde starting material and the 2,2'diamino-4,4'-bithiazole compound. As a result of the polycondensation reaction of this synthesized diphenol compound with 1,4-benzenedicarbonyl dichloride, a novel Schiff base type polyester was synthesized. Solubility, Fourier transform infrared (FTIR) spectroscopy, elemental analysis, X-ray diffraction measurements and thermogravimetric analysis (TGA) studies of the obtained polymer were performed and it showed extremely thermal stability compared to similar organic polyamides.

Ding et al. [7] synthesized a novel conjugated hyperbranched polymer containing bithiazole rings as a result of the polycondensation reaction of bifunctional 2,2'-diamino-4,4'-bithiazole and trifunctional 1,3,5-benzenetricarboxaldehyde. The hyperbranched polymer was effectively dissolved in organic polar solvents, such as dimethylsulfoxide (DMSO) and N-methylpyrrolidone, and also showed very high thermal stability. The nickel and copper transition metal complexes of this polymer exhibited the properties of soft ferromagnetic materials. In another study, He et al. [8] reported a novel Schiff base type polyester containing 2,2'-diamino4,4'-bithiazole prepared by low-temperature interface polycondensation of 1,4-benzenedicarbonyl dichloride with a diphenol compound derived from a 2,2'-diamino-4,4'-bithiazole Schiff base reacted with a 4-hydroxybenzaldehyde monomer. They characterized the synthesized polymer using FTIR spectroscopy, elemental analysis and X-ray diffrac- tion. The thermal degradation kinetics of the polymer were also investigated by TGA.

As exemplified above, studies on bithiazole-based polymers generally deal with the preparation of metal complexes of these polymers. To the best of our knowledge, with the exception of the work of $\mathrm{He}$ et al. [8], there are no studies in the literature where the thermal degradation kinetics of polymers containing bithiazole rings are studied. The present study reports the synthesis, characterization and investigation of the thermal degradation kinetics [9-15] of a new conjugated polymer containing a heterocyclic group, such as the bithiazole group. The degradation kinetics are investigated using thermogravimetric/derivative thermogravimetric (TG/DTG) techniques [16-20]. The kinetics of the pyrolysis process of the newly generated polymer give the best description of the studied pyrolysis process and allow for the determination of reliable values for the kinetic parameter. The obtained results show that the polymer is characterized by a high thermal stability and by a deceleration type decomposition mechanism.

\section{EXPERIMENTAL}

\subsection{Characterization techniques}

A Perkin Elmer Spectrum 100 FTIR spectrometer with an attenuated total reflectance accessory was used for the infrared characterization of the compounds. The spectral characterization was also performed with a Bruker $300 \mathrm{MHz}$ Ultrashield TM nuclear magnetic resonance (NMR) spectrometer at room temperature using deuterated DMSO solvent and tetramethylsilane as an internal standard. TGA experiments were obtained with a Seiko SII 7300 TG/DTA under a dynamic nitrogen gas atmosphere of $25 \mathrm{ml} / \mathrm{min}$. A controlled heating rate was applied to the polymer samples over a range of temperatures from ambient temperature to $900{ }^{\circ} \mathrm{C}$ at heating rates of $5,10,15$ and $20^{\circ} \mathrm{C} / \mathrm{min}$.

\subsection{Materials}

1,4-Dibromo-2,3-butanedione, thiourea, terephthaldialdehyde, glacial acetic acid, ammonia, triethyl amine, methanol, acetone, N,N-dimethyl formamide and ethanol were provided by SigmaAldrich. 


\subsection{Synthesis of 2,2'-diamino-4,4'-bithiazole}

The general process for the synthesis of 2,2'diamino-4,4'-bithiazole was as follows. 1,4-Dibromo-2,3-butanedione $(1.500 \mathrm{~g}, 6.151 \mathrm{mmol})$ and 50 $\mathrm{ml}$ of methanol were added into a three-necked reaction flask and the reagent dissolved. Then, thiourea $(0.9364 \mathrm{~g}, 12.302 \mathrm{mmol})$ was added to the resulting solution, which was refluxed for $12 \mathrm{~h}$ using a magnetic stirrer. The reaction mixture was then cooled to room temperature and the solvent removed on a rotary evaporator. The crude product obtained (1) was dissolved in $50 \mathrm{ml}$ of DMF by heating and then titrating with a $\mathrm{NH}_{3}$ solution to obtain the final product 2,2'-diamino-4,4'-bithiazole (2) in solid form. The compound was filtered and dried at room temperature. The synthesis scheme of 2,2'-diamino-4,4'-bithiazole is shown in Scheme 1.

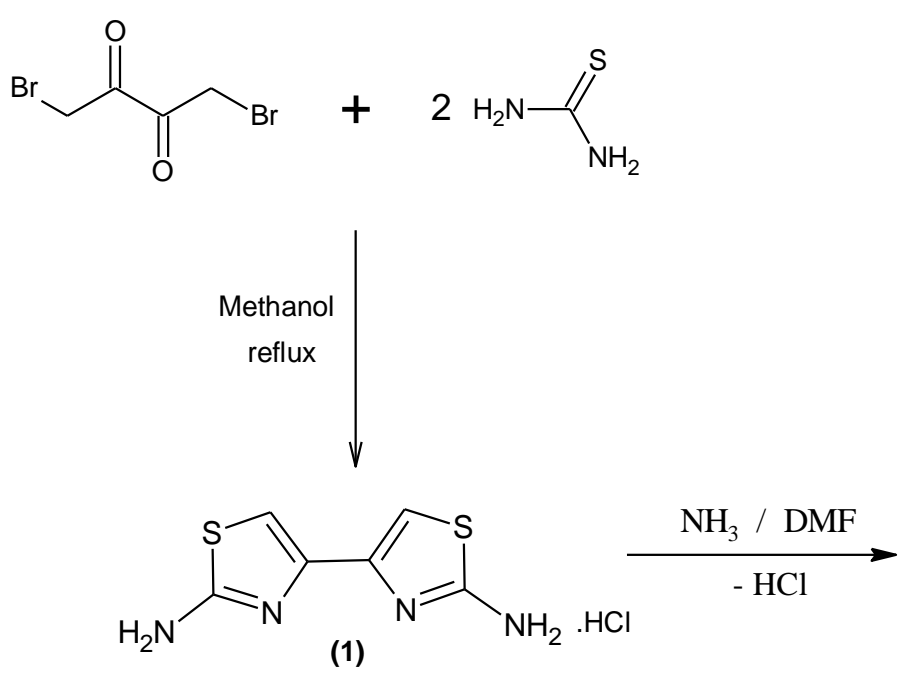

(1)<smiles>Nc1nc(-c2csc(N)n2)cs1</smiles>

(2)

Scheme 1. Synthesis of 2,2'-diamino-4,4'-bithiazole

\subsection{Synthesis of bithiazole-containing conjugated polymer}

The synthesis of the bithiazole-containing conjugated polymer was achieved by a condensation polymerization method. For this purpose, 2,2'diamino-4,4'-bithiazole $(1.000 \mathrm{~g}, 5.044 \mathrm{mmol})$ and terephthaldialdehyde $(0.6765 \mathrm{~g}, 5.044 \mathrm{mmol})$ were transferred into a three-necked reaction flask and dis- solved by adding glacial acetic acid $(100 \mathrm{ml})$. The reaction mixture was refluxed for $24 \mathrm{~h}$ on a heated magnetic stirrer. The mixture was then cooled to room temperature and precipitated in water. The resultant conjugated polymer was washed with ethanol and acetone, respectively, and then filtered and dried at room temperature. The appropriate scheme for this synthesis is shown in Scheme 2.

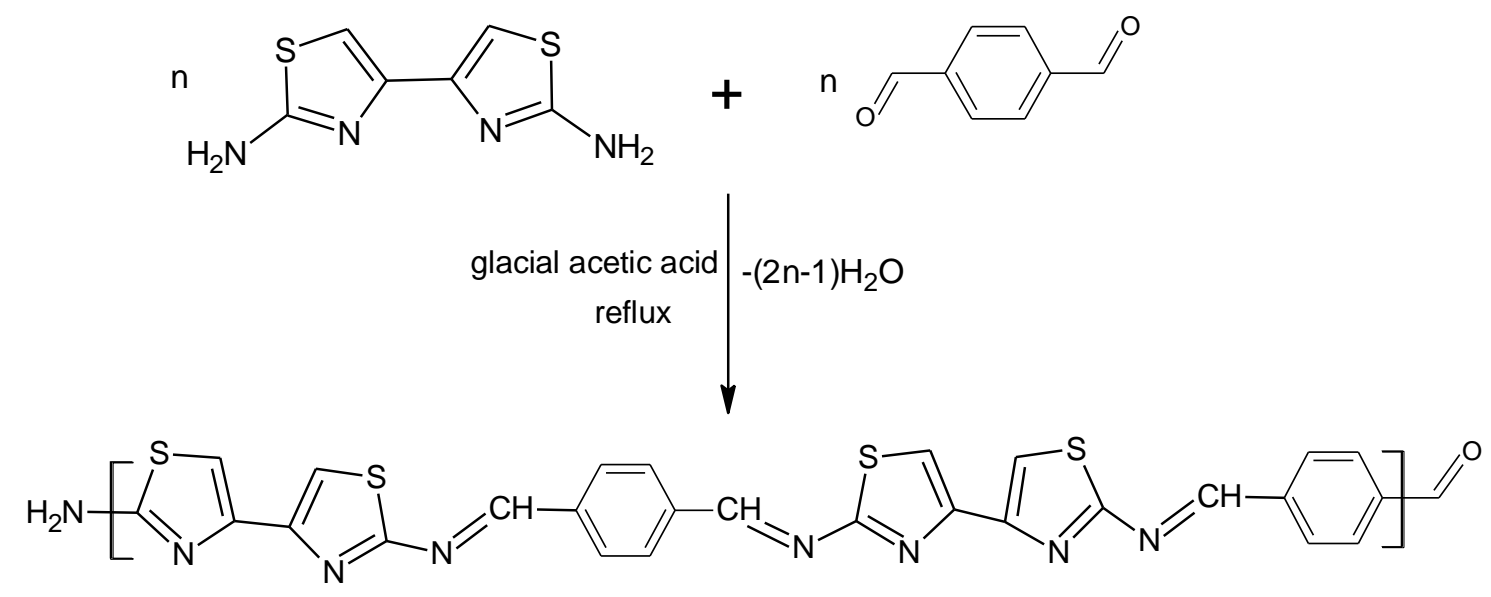

Scheme 2. Synthesis of bithiazole-containing conjugated polymer by polycondensation method 


\section{RESULTS AND DISCUSSION}

The characteristic bands in the FTIR spectrum of 2,2'-diamino-4,4'-bithiazole (Figure 1a) are observed at 3443,3281 and $3164 \mathrm{~cm}^{-1}$ for $-\mathrm{NH}_{2}$ stretching, $3127 \mathrm{~cm}^{-1}$ for $-\mathrm{C}-\mathrm{H}$ stretching, 1590 $\mathrm{cm}^{-1}$ for $-\mathrm{C}=\mathrm{N}$ stretching and other peaks at 1559 , 1389, 1292 and $1238 \mathrm{~cm}^{-1}$ for skeletal stretching vibrations in the bithiazole ring. In the ${ }^{1} \mathrm{H}-\mathrm{NMR}$ spectrum (Figure 2a), the singlet signal at 6.99 ppm is attributed to the $-\mathrm{NH}_{2}$ protons in the bithiazole ring. Another singlet signal is observed at 6.61 ppm caused by the $=\mathrm{CH}$ - protons. The signals at 3.35 and $2.50 \mathrm{ppm}$ are characteristic of DMSO solvent protons. Three different signal groups are seen in the ${ }^{13} \mathrm{C}-\mathrm{NMR}$ spectrum of the bithiazole compound, as shown in Figure 2(b). From these signals, the chemical shift at $168.50 \mathrm{ppm}$ is attributed to $\mathrm{H}_{2} \mathrm{~N}-\mathrm{C}$ carbons in the bithiazole ring. In contrast, the carbon atoms adjacent to nitrogen in the bithiazole ring show a signal at $146.99 \mathrm{ppm}$. The $=\mathrm{CH}$-carbons next to sulfur in the bithiazole ring are also observed at a $102.73 \mathrm{ppm}$ chemical shift. The $39.97 \mathrm{ppm}$ signal is due to the DMSO solvent peaks.

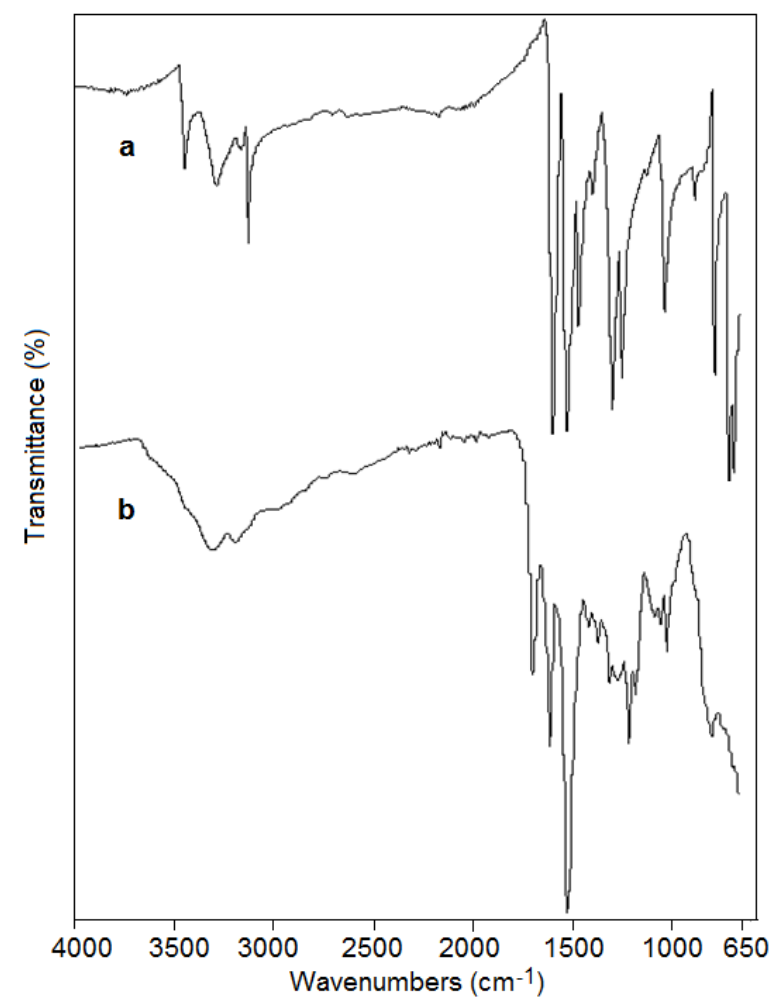

Fig. 1. FTIR spectra of (a) 2,2'-diamino-4,4'-bithiazole and (b) bithiazole-containing conjugated polymer

FTIR spectroscopy was used for the characterization of the novel conjugated polymer ob- tained as a result of the polycondensation reaction of terephthaldialdehyde with 2,2'-diamino-4,4'bithiazole. The conjugated polymer synthesized is unfortunately not soluble in chloroform, dimethyl sulfoxide, dimethylformamide, acetic acid or water [8].

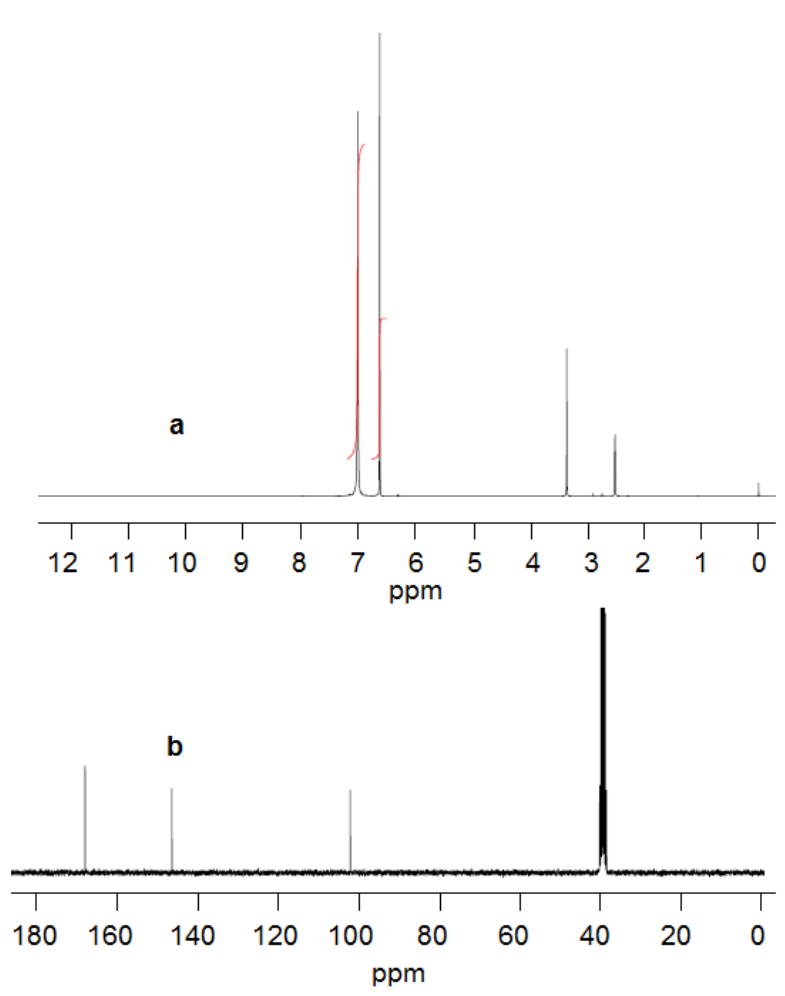

Fig. 2. (a) ${ }^{1} \mathrm{H}$ - and (b) ${ }^{13} \mathrm{C}-\mathrm{NMR}$ spectra of 2,2'-diamino-4,4'-bithiazole

The FTIR spectrum of the synthesized bithiazole-containing conjugated polymer is shown in Figure 1(b). As seen from the spectrum, the most characteristic absorption bands of the conjugated polymer are recorded at $3454-3135 \mathrm{~cm}^{-1}\left(-\mathrm{NH}_{2}\right.$ stretching vibrations at the chain end of the conjugated polymer), $2981 \mathrm{~cm}^{-1}$ (-CH stretching in the ring), $1692 \mathrm{~cm}^{-1}(-\mathrm{C}=\mathrm{O}$ stretching at the polymer chain end), $1626 \mathrm{~cm}^{-1}$ (Schiff base $-\mathrm{CH}=\mathrm{N}-$ stretching at the polymer main chain) and 1604 $\mathrm{cm}^{-1}$ (-C $=\mathrm{C}$ stretching in the bithiazole ring). The fact that the absorption bands associated with both the $-\mathrm{NH}_{2}$ and $-\mathrm{HC}=\mathrm{O}$ groups at the end of polymer main chain are located in the same spectrum proves that the condensation polymerization took place. Furthermore, apart from the band at 1590 $\mathrm{cm}^{-1}$ (Fig. 1a) due to the $-\mathrm{CH}=\mathrm{N}-$ group in 2,2'diamino-4,4'-bithiazole, by the polymerization, a new Schiff base signal is observed at $1626 \mathrm{~cm}^{-1}$ attributed to the $-\mathrm{CH}=\mathrm{N}$ - group in the polymer main chain (Fig. 1b). This new signal is evidence of a successful polymerization. Ding et al. [21] 
reported a similar approach that, as a result of the condensation reaction of 1,3,5-benzentricarboxydehyde and 2,2'-diamino-4,4'-bithiazole, showed overlapped absorptions of the both benzene and thiazole groups, but at $1624 \mathrm{~cm}^{-1}$, a new signal characteristic for $-\mathrm{C}=\mathrm{N}$ - groups in the polymer chains appeared [21].

The thermal degradation kinetics of the bithiazole-containing conjugated polymer were investigated using TGA. For this purpose, the conjugated polymer samples were heated in a nitrogen gas atmosphere from room temperature to $900{ }^{\circ} \mathrm{C}$ at different heating rates of $5,10,15$ and 20 ${ }^{\circ} \mathrm{C} / \mathrm{min}$. TGA thermograms recorded for the different heating rates are shown comparatively in Figure 3. The thermal data obtained ware also given in Table 1. As can be seen from the TGA data, the conjugated polymer generally showed a two-stage degradation tendency in the heating region from room temperature to $900{ }^{\circ} \mathrm{C}$. The first degradation region occurred in the temperature range of 250 $500{ }^{\circ} \mathrm{C}$ corresponding to a mass loss of $\sim 25 \%$. It can be seen from the thermograms at different heating rates that the degradation in the second range of $500-900{ }^{\circ} \mathrm{C}$ results in a $\sim 55 \%$ mass loss. The initial decomposition temperatures of the conjugated polymer at the heating rates of $5,10,15$ and $20{ }^{\circ} \mathrm{C} / \mathrm{min}$ are measured as $238.4,240.5,244.3$ and $252.8^{\circ} \mathrm{C}$, respectively. As the heating rate increases, a positive change is observed in the TGA thermograms and curve temperatures. This behav- ior is observed in the thermal degradation of many polymers [22-25].
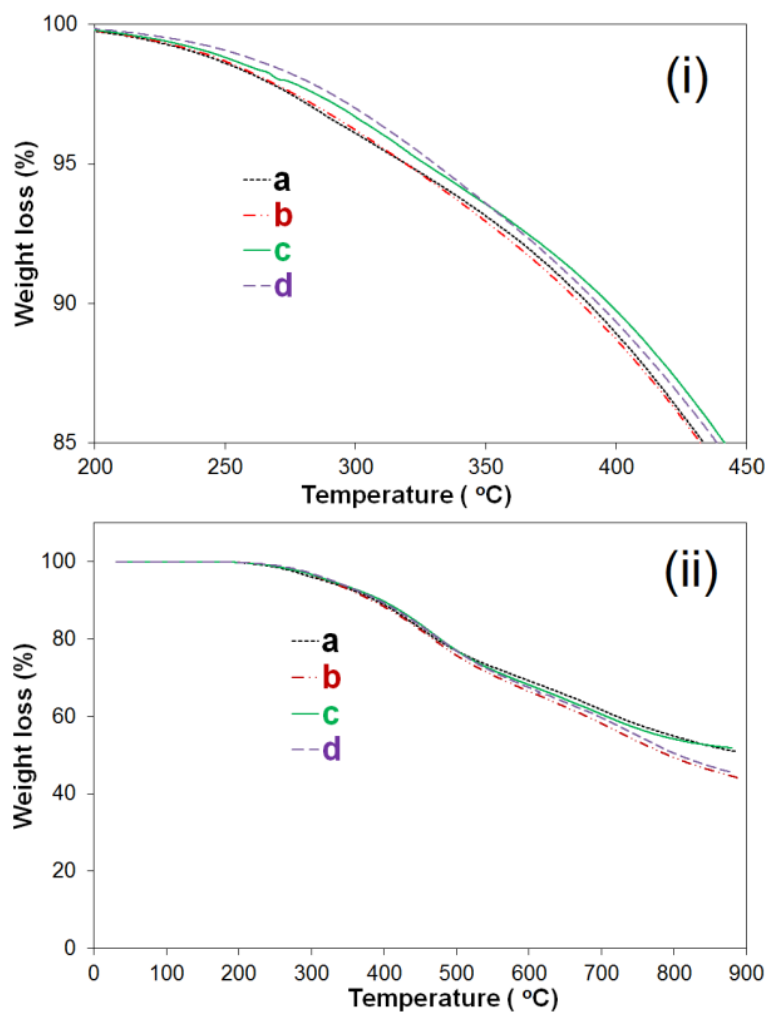

Fig. 3. TGA curves of bithiazole-containing conjugated polymer at (i) $200-450{ }^{\circ} \mathrm{C}$ and (ii) $25-900{ }^{\circ} \mathrm{C}$ for different heating rates of a) 5 , b) 10 , c) 15 and d) $20^{\circ} \mathrm{C} / \mathrm{min}$

Table 1

Thermal behavior of bithiazole-containing conjugated polymer at different heating rates

\begin{tabular}{cccccc}
\hline $\begin{array}{c}\text { Reaction } \\
\text { rate }\left({ }^{\circ} \mathrm{C} / \mathrm{min}\right)\end{array}$ & $T_{\text {initial }}\left({ }^{\circ} \mathrm{C}\right)$ & $\begin{array}{c}\text { \%Weight loss } \\
\text { at } 300{ }^{\circ} \mathrm{C}\end{array}$ & $\begin{array}{c}\% \text { Weight loss } \\
\text { at } 500{ }^{\circ} \mathrm{C}\end{array}$ & $\begin{array}{c}\% \text { Weight loss } \\
\text { at } 700{ }^{\circ} \mathrm{C}\end{array}$ & $\begin{array}{c}\% \text { Residue } \\
\text { at } 900{ }^{\circ} \mathrm{C}\end{array}$ \\
\hline 5 & 238.4 & 3.9 & 23.0 & 38.3 & 51.1 \\
10 & 240.5 & 3.8 & 24.2 & 41.8 & 44.2 \\
15 & 244.3 & 3.3 & 22.9 & 39.4 & 51.8 \\
20 & 252.8 & 3.0 & 23.1 & 40.3 & 45.5 \\
\hline \hline
\end{tabular}

The application of DTG methods holds significant promise for unraveling the mechanisms of physical and chemical processes that occur during polymer degradation. The thermal decomposition reactions of solid-state materials are defined by the following expression [26]:

$$
\frac{\mathrm{d} \alpha}{\mathrm{d} t}=A e^{-\frac{E}{R T}} f(\alpha)
$$

where $f(\alpha)$ is the particular reaction model describing the dependence of the reaction rate on the extent of the reaction, $\alpha$ represents the extent of the reaction, which can be determined from TGA runs as a fractional mass loss, $\mathrm{R}$ is the ideal gas constant, $T$ is the absolute temperature, $t$ is time and $A$ and $E$ are the pre-exponential factor and activation energy, respectively.

In addition, $g(\alpha)$ is defined as the integral function of conversion as expressed by:

$$
g(\alpha)=\int_{0}^{\alpha_{\mathrm{p}}} \frac{\mathrm{d} \alpha}{f(\alpha)}=\frac{A}{\beta} \int_{0}^{\mathrm{T}_{\mathrm{p}}} \mathrm{e}^{-\frac{\mathrm{E}}{\mathrm{RT}}} \mathrm{d} T
$$


where $\beta$ is the heating rate. The thermal decomposition of polymeric materials generally follows one of the decomposition processes of the sigmoidal and deceleration type mechanism [27]. Various statements of $g(\alpha)$ integral functions are given in Table 2. By using these functions, the thermal decomposition mechanisms may easily be determined by TGA [28].

Table 2

Algebraic expressions for $g(\alpha)$ for the most frequently used mechanisms of solid-state processes

\begin{tabular}{lll}
\hline \hline Symbol & $g(\alpha)$ & Solid state processes \\
\hline $\mathrm{A}_{2}$ & {$[-\ln (1-\alpha)]^{1 / 2}$} & Nucleation and growth (Avrami equation 1) \\
$\mathrm{A}_{3}$ & {$[-\ln (1-\alpha)]^{1 / 3}$} & $\begin{array}{l}\text { Nucleation and growth (Avrami equation 2) } \\
\mathrm{A}_{4}\end{array}$ \\
$\begin{array}{l}\text { Deceleration curves } \\
\mathrm{R}_{1}\end{array}$ & $\mathrm{~A}(1-\alpha)]^{1 / 4}$ & Nucleation and growth (Avrami equation 3) \\
$\mathrm{R}_{2}$ & {$\left[1-(1-\alpha)^{1 / 2}\right]$} & Phase boundary controlled reaction (one-dimensional movement) \\
$\mathrm{R}_{3}$ & {$\left[1-(1-\alpha)^{1 / 3}\right]$} & Phase boundary controlled reaction (contraction area) \\
$\mathrm{D}_{1}$ & $\alpha^{2}$ & Phase boundary controlled reaction (contraction volume) \\
$\mathrm{D}_{2}$ & $(1-\alpha) \ln (1-\alpha)+\alpha$ & One-dimensional diffusion \\
$\mathrm{D}_{3}$ & {$\left[1-(1-\alpha)^{1 / 3}\right]^{2}$} & Two-dimensional diffusion \\
$\mathrm{D}_{4}$ & $(1-2 / 3 \alpha)(1-\alpha)^{2 / 3}$ & Three-dimensional diffusion (Jander equation) \\
$\mathrm{F}_{1}$ & $-\ln (1-\alpha)$ & Three-dimensional diffusion (Ginstling-Brounshtein equation) \\
$\mathrm{F}_{2}$ & $1 /(1-\alpha)$ & Random nucleation with one nucleus on the individual particle \\
$\mathrm{F}_{3}$ & $1 /(1-\alpha)^{2}$ & Random nucleation with two nuclei on the individual particle \\
\hline \hline
\end{tabular}

Using the data obtained from the decomposition thermograms, the thermal decomposition activation energies of the conjugated polymer were determined separately according to the FlynnWall-Ozawa [9, 10] and Kissinger [11] methods. The main purpose of using these two methods is that both methods are integral for determining the activation energies without the need to know the reaction order and the degradation mechanism [27]. The Flynn-Wall-Ozawa method uses the following equation:

$$
\log \beta=\log \left[\frac{A E}{g(\alpha) \mathrm{R}}\right]-2.315-\frac{0.457 E}{\mathrm{R} T}
$$

where $E$ is the decomposition activation energy calculated from the slope of $\log \beta$ versus $1000 / T$ plots. For this method, the measurements at different conversion percentages $(3 \%, 5 \%, 7 \%, 9 \%$, $11 \%, 13 \%$ and $15 \%$ ) were taken. To calculate the activation energies at these conversion degrees, the $\log \beta$ versus $1000 / T$ lines were plotted, as shown in Figure 4, where the fitted straight lines are nearly parallel, thus indicating the applicability of this method to the conjugated polymer in the conversion range studied. From the slope of a series line obtained, the activation energy corresponding to each conversion percentage was calculated separately and the values are given in Table 3 . Among these values, the average activation energy value for the conjugated polymer was calculated as 288.4 $\mathrm{kJ} / \mathrm{mol}$. The closest value to the calculated average activation energy value was obtained with the value corresponding to $288.5 \mathrm{~kJ} / \mathrm{mol}$ at the conversion of $11 \%$. An increase in the activation energy values was also observed depending on the increase in the percentages of decomposition [16-18, 29].

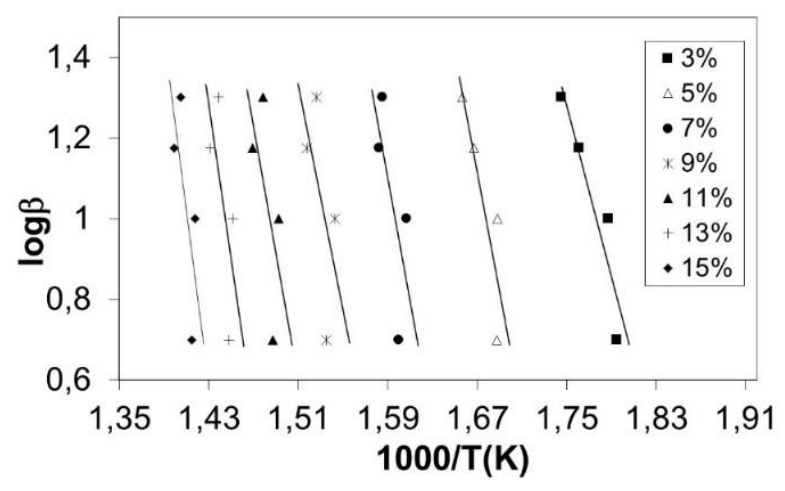

Fig. 4. Flynn-Wall-Ozawa lines at different conversion values 
T a ble 3

\begin{tabular}{ccc}
$\begin{array}{c}\text { Activation energies of bithiazole-containing } \\
\text { conjugated polymer calculated from } \\
\text { Flynn-Wall-Ozawa method }\end{array}$ \\
\hline \hline \multicolumn{4}{c}{ m $(\%)$} & $E(\mathrm{~kJ} / \mathrm{mol})$ & $R^{2}$ \\
\hline 3 & 193.0 & 0.871 \\
5 & 269.2 & 0.766 \\
7 & 278.2 & 0.470 \\
9 & 253.7 & 0.337 \\
11 & 288.5 & 0.377 \\
13 & 344.6 & 0.444 \\
15 & 391.6 & 0.509 \\
\hline Mean & 288.4 & \\
\hline \hline
\end{tabular}

In order to evaluate the thermal degradation kinetics of the bithiazole-containing conjugated polymer, the Kissinger method, another kinetic method independent of reaction order, was used to support and confirm the thermal degradation activation energies calculated from the Flynn-WallOzawa method. This method is expressed as follows:

$$
\ln \left(\frac{\beta}{T_{\max }^{2}}\right)=\left\{\ln \frac{A \mathrm{R}}{E}+\ln \left[n\left(1-\alpha_{\max }\right)^{n-1}\right]\right\}-\frac{E}{\mathrm{R} T_{\max }}
$$

where $T_{\max }$ is the temperature corresponding to the maximum reaction rate, $\alpha_{\max }$ is the maximum conversion at $T_{\max }$ and $n$ is the reaction order. According to this method, the thermal degradation activation energy, $E$, can be calculated from the slope of a plot of $\ln \left(\beta / T^{2}{ }_{\max }\right)$ versus $1000 / T_{\max }$. The graph drawn according to the Kissinger method is shown in Figure 5. The $T_{\max }$ values required to calculate the activation energy were determined from DTG as $450.0,460.2,465.4$ and $471.5^{\circ} \mathrm{C}$ at the heating rates of $5,10,15$ and $20^{\circ} \mathrm{C} / \mathrm{min}$, respectively. The activation energy was calculated as $281.1 \mathrm{~kJ} / \mathrm{mol}$ from the slope of the Kissinger line, as seen in Figure 5. The linearity for this line was found to be $\mathrm{R}^{2}=0.994$. The activation energies of both the Kissinger and Flynn-Wall-Ozawa methods are very similar, with only a $7.3 \mathrm{~kJ} / \mathrm{mol}$ difference between them, thereby illustrating the reliability of the results $[16,17,29]$.

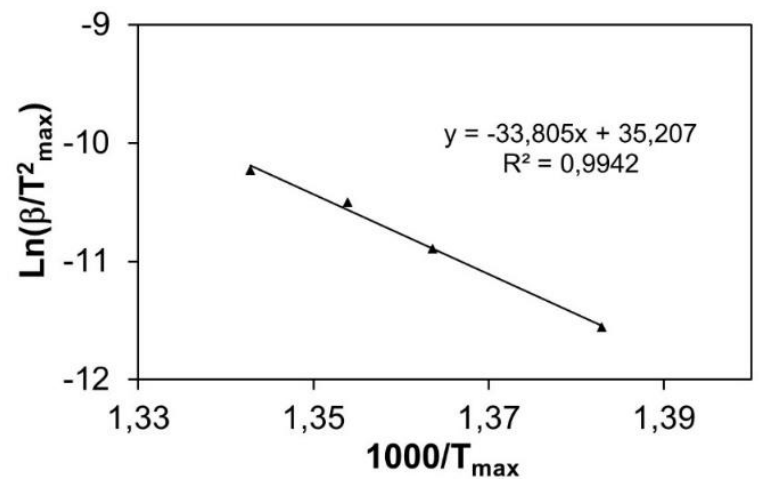

Fig. 5. $\ln \left(\beta / T^{2}{ }_{\max }\right)$ versus $1000 / T_{\max }$ plots obtained from Kissinger method

The thermal degradation mechanism of the bithiazole-containing conjugated polymer was determined when the activation energies calculated from the various kinetic methods in the literature were compared with the activation energies obtained from the Flynn-Wall-Ozawa and Kissinger methods. These integral methods are CoatsRedfern [12], Tang [13], van Krevelen [14] and Horowitz-Metzger [15]. When these methods are used, the accuracy between the energy values for calculating the thermal decomposition mechanisms of the polymer is increased. These methods are briefly described below.

The Coats-Redfern method is one of the most used integral methods and it involves the thermal degradation mechanism. Using an asymptotic approximation for the solution of Eq. (2), the following equation can be obtained for this method:

$$
\ln \frac{g(\alpha)}{T^{2}}=\ln \frac{A \mathrm{R}}{\beta E}-\frac{E}{\mathrm{R} T}
$$

According to the various decomposition processes, the apparent activation energies of each $g(\alpha)$ function can be determined from a plot of $\ln \left(g(\alpha) / T^{2}\right)$ versus $1000 / T$.

The Tang method can also be used to determine the thermal decomposition mechanism of the conjugated polymer:

$$
\ln \left[\frac{g(\alpha)}{T^{1.89466100}}\right]=\left[\ln \frac{A E}{\beta \mathrm{R}}+3.63504095-1.89466100 \ln E\right]-1.00145033 \frac{E}{\mathrm{R} T}
$$

where the activation energy is calculated from the slope of the plot of $\ln \left(g(\alpha) / T^{1.89466100}\right)$ versus $1000 / T$ for every $g(\alpha)$ function.
In addition to the above kinetic methods, the van Krevelen method is also used to determine the 
decomposition mechanism of the polymer. This method is expressed as below:

$$
\log g(\alpha)=\log B+\left(\frac{E}{\mathrm{R} T_{r}}+1\right) \log T
$$

where $T_{r}$ is a reference temperature that represents the maximum temperature rate obtained from DTG. The slope of $\log g(\alpha)$ versus $\log T$ gives the activation energy for each $g(\alpha)$ function.

The Horowitz-Metzger method simplifies the exponential integral using an approximation similar to the van Krevelen method, defining a characteristic temperature $\theta$ such that $\theta=T-T_{r}$. By making this approximation, the following equation is obtained:

$$
\ln g(\alpha)=\frac{E \theta}{R T_{r}^{2}}
$$

The slope obtained from the $\ln g(\alpha)$ versus $T$ plots is equal to the value of $E / R T_{\mathrm{r}}^{2}$, in which the activation energy is calculated for each $g(\alpha)$ func- tion of the solid-state degradation mechanisms. In order to obtain reproducible results, the reference temperature is taken as that corresponding to the maximum temperature rate.

The thermal decomposition activation energies and linear regressions for various statements of $g(\alpha)$ integral functions determined in the range of $3-15 \%$ are summarized in Tables 4 to 7 for the various kinetic models at the heating rates of 5,10 , 15 and $20{ }^{\circ} \mathrm{C} / \mathrm{min}$. When these tables are examined, the deceleration type dimensional diffusion mechanisms $\left(D_{n}\right)$ are evident in all methods because the activation energies calculated for these mechanisms are close to the activation energies calculated from the Flynn-Wall-Ozawa ( $E=288.4$ $\mathrm{kJ} / \mathrm{mol})$ and Kissinger $(E=281.1 \mathrm{~kJ} / \mathrm{mol})$ methods. In particular, between the $\mathrm{D}_{\mathrm{n}}$ diffusion type deceleration mechanisms, the activation energy corresponding to the $\mathrm{D}_{3}$ three-dimensional diffusion (Jander equation) type deceleration mechanism is remarkable at the heating rate of $20{ }^{\circ} \mathrm{C} / \mathrm{min}$ with regards to its closeness to the Kissinger and FlynnWall-Ozawa methods.

Table 4

Activation energies of bithiazole-containing conjugated polymer using Coats-Redfern method

\begin{tabular}{ccccccccc}
\hline \hline \multirow{2}{*}{ Mechanism } & \multicolumn{7}{c}{ Heating Rate } \\
\cline { 2 - 9 } & \multicolumn{2}{c}{$5^{\circ} \mathrm{C} / \mathrm{min}$} & \multicolumn{2}{c}{$10^{\circ} \mathrm{C} / \mathrm{min}$} & \multicolumn{2}{c}{${ }^{\circ} \mathrm{C} / \mathrm{min}$} & \multicolumn{2}{c}{$20^{\circ} \mathrm{C} / \mathrm{min}$} \\
\cline { 2 - 9 } & $E(\mathrm{~kJ} / \mathrm{mol})$ & $R^{2}$ & $E(\mathrm{~kJ} / \mathrm{mol})$ & $R^{2}$ & $E(\mathrm{~kJ} / \mathrm{mol})$ & $R^{2}$ & $E(\mathrm{~kJ} / \mathrm{mol})$ & $R^{2}$ \\
\hline $\mathrm{A}_{2}$ & 7.6 & 0.990 & 8.0 & 0.981 & 8.1 & 0.979 & 9.5 & 0.975 \\
$\mathrm{~A}_{3}$ & 1.6 & 0.884 & 1.9 & 0.832 & 1.9 & 0.823 & 2.8 & 0.864 \\
$\mathrm{~A}_{4}$ & 1.6 & 0.886 & 1.2 & 0.743 & 1.2 & 0.735 & 0.6 & 0.284 \\
$\mathrm{R}_{1}$ & 24.2 & 0.996 & 25.0 & 0.992 & 25.4 & 0.991 & 28.0 & 0.989 \\
$\mathrm{R}_{2}$ & 24.9 & 0.997 & 25.7 & 0.993 & 26.1 & 0.992 & 28.7 & 0.990 \\
$\mathrm{R}_{3}$ & 25.1 & 0.997 & 26.0 & 0.994 & 26.4 & 0.993 & 29.0 & 0.991 \\
$\mathrm{D}_{1}$ & 58.9 & 0.998 & 60.5 & 0.995 & 61.4 & 0.995 & 66.5 & 0.993 \\
$\mathrm{D}_{2}$ & 59.8 & 0.998 & 61.4 & 0.996 & 62.4 & 0.995 & 65.6 & 0.993 \\
$\mathrm{D}_{3}$ & 60.7 & 0.998 & 62.4 & 0.996 & 63.3 & 0.995 & 68.6 & 0.994 \\
$\mathrm{D}_{4}$ & 60.1 & 0.998 & 61.8 & 0.996 & 62.7 & 0.995 & 67.9 & 0.993 \\
$\mathrm{~F}_{1}$ & 28.7 & 0.997 & 26.5 & 0.994 & 26.9 & 0.993 & 29.5 & 0.991 \\
$\mathrm{~F}_{2}$ & 7.6 & 0.998 & 7.5 & 0.998 & 7.6 & 0.998 & 7.4 & 0.998 \\
$\mathrm{~F}_{3}$ & 4.8 & 0.958 & 4.6 & 0.965 & 4.7 & 0.960 & 4.2 & 0.960 \\
\hline \hline
\end{tabular}

The activation energy for every $g(\alpha)$ function listed in Table 1 was proposed using the Coats-Redfern method with Eq. (5). These values were obtained at constant heating rates from the fitting of $\ln \left(g(\alpha) / T^{2}\right)$ versus $1000 / T$ plots. The same conversion values are used for this study. Table 4 shows the activation energies and correlations for conversions in the range of $3-15 \%$ at heating rates of 5, 10, 25 and $20{ }^{\circ} \mathrm{C} / \mathrm{min}$. Analysis of this table shows that, at all the heating rate values, the activation energies are in better agreement with those obtained using the Kissinger method corresponding to a $D_{n}$ type mechanism. In addition, it can be seen that the optimum heating rate is $20{ }^{\circ} \mathrm{C} / \mathrm{min}$, at which the activation energy corresponding to a $\mathrm{D}_{3}$ mechanism is $68.6 \mathrm{~kJ} / \mathrm{mol}$ with good correlation $\left(R^{2}=0.998\right)$. For the Tang method, Eq. (6) was used to obtain the activation energy, which could 
be calculated from the slope of the plots of $\ln$ $\left(g(\alpha) / T^{1.89466100}\right)$ versus $1000 / T$ for every $g(\alpha)$ function. When it is considered for this method, as given in Table 5 , at a heating rate of $20^{\circ} \mathrm{C} / \mathrm{min}$, the activation energy corresponding to the $\mathrm{D}_{3}$ mechanism is $E=69.1 \mathrm{~kJ} / \mathrm{mol}$ with a good linear regres- sion $\left(R^{2}=0.994\right)$. This value is relatively close to the Flynn-Wall-Ozawa and Kissinger methods. These results strongly suggest that the solid-state thermodegradation mechanism followed by this conjugated polymer is a deceleration $\left(D_{n}\right)$ type mechanism.

Table 5

Activation energies of bithiazole-containing conjugated polymer using Tang method

\begin{tabular}{ccccccccc}
\hline \hline \multirow{2}{*}{ Mechanism } & \multicolumn{7}{c}{ Heating rate } \\
\cline { 2 - 9 } & \multicolumn{2}{c}{$5{ }^{\circ} \mathrm{C} / \mathrm{min}$} & \multicolumn{2}{c}{$10^{\circ} \mathrm{C} / \mathrm{min}$} & \multicolumn{2}{c}{$15^{\circ} \mathrm{C} / \mathrm{min}$} & \multicolumn{2}{c}{$20^{\circ} \mathrm{C} / \mathrm{min}$} \\
\cline { 2 - 9 } & $E(\mathrm{~kJ} / \mathrm{mol})$ & $R^{2}$ & $E(\mathrm{~kJ} / \mathrm{mol})$ & $R^{2}$ & $E(\mathrm{~kJ} / \mathrm{mol})$ & $R^{2}$ & $E(\mathrm{~kJ} / \mathrm{mol})$ & $R^{2}$ \\
\hline $\mathrm{A}_{2}$ & 8.1 & 0.992 & 8.5 & 0.984 & 8.7 & 0.982 & 10.0 & 0.978 \\
$\mathrm{~A}_{3}$ & 2.1 & 0.935 & 2.4 & 0.896 & 2.5 & 0.889 & 3.3 & 0.904 \\
$\mathrm{~A}_{4}$ & 0.8 & 0.755 & 0.6 & 0.473 & 0.6 & 0.458 & 8.3 & 0.000 \\
$\mathrm{R}_{1}$ & 24.7 & 0.996 & 25.5 & 0.993 & 26.4 & 0.992 & 28.5 & 0.989 \\
$\mathrm{R}_{2}$ & 25.4 & 0.997 & 26.3 & 0.994 & 26.6 & 0.993 & 29.3 & 0.991 \\
$\mathrm{R}_{3}$ & 25.7 & 0.997 & 26.5 & 0.994 & 26.9 & 0.993 & 29.5 & 0.991 \\
$\mathrm{D}_{1}$ & 59.3 & 0.998 & 61.0 & 0.995 & 61.9 & 0.995 & 67.0 & 0.993 \\
$\mathrm{D}_{2}$ & 60.2 & 0.998 & 61.9 & 0.996 & 62.8 & 0.995 & 68.0 & 0.993 \\
$\mathrm{D}_{3}$ & 61.2 & 0.998 & 62.9 & 0.996 & 63.8 & 0.995 & 69.1 & 0.994 \\
$\mathrm{D}_{4}$ & 60.6 & 0.998 & 62.2 & 0.996 & 63.2 & 0.995 & 68.4 & 0.994 \\
$\mathrm{~F}_{1}$ & 26.1 & 0.997 & 27.0 & 0.995 & 27.4 & 0.994 & 30.0 & 0.992 \\
$\mathrm{~F}_{2}$ & 7.0 & 0.997 & 7.0 & 0.998 & 7.1 & 0.997 & 6.9 & 0.998 \\
$\mathrm{~F}_{3}$ & 4.2 & 0.945 & 4.1 & 0.953 & 4.1 & 0.947 & 3.7 & 0.945 \\
\hline \hline
\end{tabular}

The activation energies and correlations were calculated using the van Krevelen and Horowitz-Metzger methods in order to confirm this deceleration behavior and increase the accuracy of the measurements. The activation energies are ob- tained through the linear fitting of $\log g(\alpha)$ versus $\log T$ plots using Eq. (7). Table 6 shows the activation energies and correlation values for various $\mathrm{g}(\alpha)$ mechanisms at different constant heating rates obtained from the van Krevelen method.

Table 6

Activation energies of bithiazole-containing conjugated polymer using van Krevelen method

\begin{tabular}{ccccccccc}
\hline \hline \multirow{2}{*}{ Mechanism } & \multicolumn{7}{c}{ Heating Rate } \\
\cline { 2 - 9 } & \multicolumn{2}{c}{$5^{\circ} \mathrm{C} / \mathrm{min}$} & \multicolumn{2}{c}{$10^{\circ} \mathrm{C} / \mathrm{min}$} & \multicolumn{2}{c}{$1{ }^{\circ} \mathrm{C} / \mathrm{min}$} & \multicolumn{2}{c}{$20^{\circ} \mathrm{C} / \mathrm{min}$} \\
\cline { 2 - 9 } & $E(\mathrm{~kJ} / \mathrm{mol})$ & $R^{2}$ & $E(\mathrm{~kJ} / \mathrm{mol})$ & $R^{2}$ & $E(\mathrm{~kJ} / \mathrm{mol})$ & $R^{2}$ & $E(\mathrm{~kJ} / \mathrm{mol})$ & $R^{2}$ \\
\hline $\mathrm{A}_{2}$ & 14.7 & 0.997 & 15.4 & 0.994 & 15.5 & 0.994 & 17.2 & 0.992 \\
$\mathrm{~A}_{3}$ & 13.8 & 0.997 & 8.2 & 0.994 & 138.5 & 0.994 & 9.4 & 0.992 \\
$\mathrm{~A}_{4}$ & 4.4 & 0.997 & 4.6 & 0.994 & 4.7 & 0.994 & 5.5 & 0.992 \\
$\mathrm{R}_{1}$ & 33.9 & 0.996 & 35.3 & 0.993 & 35.6 & 0.993 & 38.7 & 0.990 \\
$\mathrm{R}_{2}$ & 34.1 & 0.996 & 36.1 & 0.994 & 36.4 & 0.993 & 39.6 & 0.991 \\
$\mathrm{R}_{3}$ & 35.0 & 0.997 & 36.4 & 0.994 & 36.7 & 0.993 & 39.9 & 0.991 \\
$\mathrm{D}_{1}$ & 73.8 & 0.996 & 76.6 & 0.995 & 77.2 & 0.993 & 83.6 & 0.990 \\
$\mathrm{D}_{2}$ & 74.8 & 0.996 & 77.7 & 0.993 & 78.3 & 0.993 & 84.8 & 0.991 \\
$\mathrm{D}_{3}$ & 75.9 & 0.997 & 78.8 & 0.994 & 79.5 & 0.994 & 83.0 & 0.991 \\
$\mathrm{D}_{4}$ & 75.2 & 0.996 & 78.1 & 0.994 & 78.7 & 0.993 & 85.2 & 0.991 \\
$\mathrm{~F}_{1}$ & 35.5 & 0.997 & 424.3 & 0.994 & 37.2 & 0.994 & 40.5 & 0.992 \\
$\mathrm{~F}_{2}$ & -2.7 & 0.960 & -2.7 & 0.969 & -2.7 & 0.966 & -2.5 & 0.976 \\
$\mathrm{~F}_{3}$ & 5.3 & 0.960 & 7.2 & 0.969 & 7.2 & 0.966 & 1.2 \\
\hline \hline
\end{tabular}


As can be seen from this table, the $\mathrm{D}_{3}$ mechanism at a heating rate of $20{ }^{\circ} \mathrm{C} / \mathrm{min}$ gives results $\left(E=83.0 \mathrm{~kJ} / \mathrm{mol}\right.$ and $\left.R^{2}=0.991\right)$ in better agreement with those of the Flynn-Wall-Ozawa and Kissinger methods. In addition, by using the Horowitz and Metzger model, the activation energies and correlations obtained for each $g(\alpha)$ function of the solid-state degradation mechanisms are calcu- lated from the slope of $\ln g(\alpha)$ versus $T$ plots drawn according to Eq. (8). The obtained results are also listed in Table 7. Again, the best agreement with the Flynn-Wall-Ozawa and Kissinger methods corresponds to a $\mathrm{D}_{3}$ deceleration mechanism at a heating rate of $20{ }^{\circ} \mathrm{C} / \mathrm{min}$, where the apparent activation energy is found to be $E=137.8 \mathrm{~kJ} / \mathrm{mol}\left(R^{2}\right.$ $=0.985$ ).

\section{T a ble 7}

Activation energies of bithiazole-containing conjugated polymer using Horowitz-Metzger method

\begin{tabular}{ccccccccc}
\hline \hline & \multicolumn{7}{c}{ Heating rate } \\
\cline { 2 - 9 } Mechanism & \multicolumn{2}{c}{$5{ }^{\circ} \mathrm{C} / \mathrm{min}$} & \multicolumn{2}{c}{$10^{\circ} \mathrm{C} / \mathrm{min}$} & ${ }^{\circ} \mathrm{C} / \mathrm{min}$ & \multicolumn{2}{c}{$20^{\circ} \mathrm{C} / \mathrm{min}$} \\
\cline { 2 - 9 } & $E(\mathrm{~kJ} / \mathrm{mol})$ & $R^{2}$ & $E(\mathrm{~kJ} / \mathrm{mol})$ & $R^{2}$ & $E(\mathrm{~kJ} / \mathrm{mol})$ & $R^{2}$ & $E(\mathrm{~kJ} / \mathrm{mol})$ & $R^{2}$ \\
\hline $\mathrm{A}_{2}$ & 28.6 & 0.993 & 29.4 & 0.989 & 29.6 & 0.989 & 31.3 & 0.986 \\
$\mathrm{~A}_{3}$ & 19.1 & 0.993 & 19.6 & 0.989 & 19.8 & 0.989 & 20.9 & 0.986 \\
$\mathrm{~A}_{4}$ & 14.3 & 0.993 & 14.7 & 0.989 & 14.8 & 0.989 & 15.6 & 0.986 \\
$\mathrm{R}_{1}$ & 55.8 & 0.992 & 57.3 & 0.987 & 57.8 & 0.987 & 61.0 & 0.983 \\
$\mathrm{R}_{2}$ & 60.7 & 0.992 & 62.2 & 0.988 & 62.8 & 0.988 & 66.1 & 0.985 \\
$\mathrm{R}_{3}$ & 63.3 & 0.993 & 64.9 & 0.988 & 65.5 & 0.989 & 68.8 & 0.985 \\
$\mathrm{D}_{1}$ & 111.6 & 0.992 & 114.7 & 0.987 & 115.6 & 0.987 & 122.0 & 0.983 \\
$\mathrm{D}_{2}$ & 116.7 & 0.992 & 119.8 & 0.988 & 120.8 & 0.988 & 127.4 & 0.984 \\
$\mathrm{D}_{3}$ & 126.7 & 0.993 & 129.9 & 0.988 & 131.0 & 0.989 & 137.8 & 0.985 \\
$\mathrm{D}_{4}$ & 126.0 & 0.992 & 129.3 & 0.988 & 130.4 & 0.988 & 137.0 & 0.984 \\
$\mathrm{~F}_{1}$ & 57.2 & 0.993 & 58.8 & 0.989 & 59.3 & 0.989 & 62.6 & 0.986 \\
$\mathrm{~F}_{2}$ & 2.8 & 0.972 & 2.9 & 0.979 & 2.9 & 0.976 & 3.2 & 0.984 \\
$\mathrm{~F}_{3}$ & 5.6 & 0.972 & 5.8 & 0.979 & 5.8 & 0.976 & 6.4 & 0.984 \\
\hline \hline
\end{tabular}

\section{CONCLUSIONS}

The thermal degradation kinetics of a new bithiazole-containing conjugated polymer was investigated by thermogravimetric analysis at different heating rates. The thermal decomposition activation energies of the conjugated polymer were found to be 288.4 and $281.1 \mathrm{~kJ} / \mathrm{mol}$ by the FlynnWall-Ozawa and Kissinger methods, respectively. The best conformity in all the kinetic methods and the heating rates was obtained in the case of the Horowitz-Metzger method for a three-dimensional diffusion type deceleration $\mathrm{D}_{3}$ mechanism at a heating rate of $20^{\circ} \mathrm{C} / \mathrm{min}$.

\section{REFERENCES}

[1] B. B. Çarbaş, Conjugated polymers and their energy applications, The Journal of Global Engineering Studies, 3, 46-60 (2016).

[2] P. A. Sobarzo, A. F. González, E. Schott, L. H. Tagle, A. Tundidor-Camba, G. H. Carmen, I. A. Jessop, C. A. Terraza. New triphenylamine-based oligomeric schiff bases containing tetraphenylsilane moieties in the backbone, Polymers, 11, 1-15 (2019).

DOI:10.3390/polym 11020216
[3] M. M. Hashemi, H. Asadollahi, R. Mostaghim, Microwave-assisted synthesis of bithiazole derivatives under solvent-free conditions, Russ. J. Org., 41, 623-624 (2005). DOI: 10.1002/chin.200542144

[4] J. Weng, L. M. Jiang, W. L. Sun, Z. Q. Shen, S. Q. Liang, Syntheses and magnetic properties of novel complexes of polymer containing bithiazole ring and salicylic acid, Polymer, 42, 5491-5494 (2001). DOI: https://doi.org/10.1016/S0032-3861(01)00009-X

[5] W. Sun, L. Jiang, J. Weng, B. He, D. Cen, Z. Shen, A novel bithiazole-tetrathiapentalene polymer and its metal complexes, React. Funct. Polym., 55, 249-254 (2003). DOI:10.1016/S1381-5148(03)00013-0

[6] F. Deng, W. He, A. S. Luyt, Y. Y. Jiang, Synthesis and properties of a novel polyester containing bithiazole, Chin. Chem. Lett., 22, 109-113 (2011).

DOI: $10.1016 /$ j.cclet.2010.09.019

[7] N. Ding, W. Lin, W. Sun, Z. Shen, A novel hyperbranched aromatic polyamide containing bithiazole: Synthesis, metal complexation and magnetic properties, Sci. China Chem., 54, 320-325 (2011). DOI: $10.1007 / \mathrm{s} 11426-010-4211-9$

[8] W. He, Y. Y. Jiang, A. S. Luyt, R. O. Ocaya, T. J. Ge. Synthesis and degradation kinetics of a novel polyester containing bithiazole rings, Thermochim. Acta, 525, 915 (2011). DOI: 10.1016/j.tca.2011.07.015 
[9] J. H. Flynn, L. A. Wall, A quick, direct method for the determination of activation energy from thermogravimetric data, J. Polym. Sci. B, 4, 323-328 (1966). DOI: https://doi.org/10.1002/pol.1966.110040504

[10] T. Ozawa, Applicability of Friedman plot, J. Therm. Anal. 31, 547-551 (1986). DOI: 10.1007/BF01914230

[11] H. E. Kissinger, Reaction kinetics in differential thermal analysis, Anal. Chem. 29, 1702-1706 (1957). DOI: 10.1021/ac60131a045.

[12] A. W. Coats, J. P. Redfern, Kinetic parameters from thermogravimetric data, Nature, 201, 68-69 (1964). DOI: $10.1038 / 201068 \mathrm{a} 0$.

[13] W. Tang, Y. Liu, H. Zhang, C. Wang, New approximate formula for Arrhenius temperature integral, Thermochim. Acta, 408, 39-43 (2003). DOI: 10.1016/S0040-6031(03)00310-1.

[14] D. W. van Krevelen, C. van Herrden, F. J. Hutjens, Kinetic study by thermogravimetry, Fuel, 30, 253-258 (1951).

[15] H. H. Horowitz, G. Metzger, A new analysis of thermogravimetric traces. Anal. Chem., 35, 1464-1468 (1963). DOI: https://doi.org/10.1021/ac60203a013

[16] L. Nunez, F. Fraga, M. R. Nunez, M. Villanueva, Thermogravimetric study of the decomposition process of the system BADGE $(\mathrm{n}=0) / 1,2$ DCH, Polymer 41, 46354641 (2000). DOI: 10.1016/S0032-3861(99)00687-4

[17] A. Kurt, H. İ. Avc1, M. Koca, Synthesis and characterization of a novel isocoumarin derived polymer and its thermal decomposition kinetics, Maced. J. Chem. Chem. En. 37, 173-184 (2018).

DOI: $10.20450 /$ mjcce.2018.1503.

[18] A. Kurt, M. Koca, Synthesis, characterization and thermal degradation kinetics of poly(3-acetylcoumarin-7-ylmethacrylate) and its organoclay nanocomposites, Journal of Eng. Research 4, 46-65 (2016).

[19] A. Kurt, A. F. Ayhan, M. Koca, Thermal decomposition kinetics of a coumarin based copolymer: poly(3-benzoyl coumarin-7-yl-methacrylate:0.54-co-methyl methacrylate : 0.46), Mal. J. Fund. Appl. Sci., 15, 206-211 (2019). DOI: 10.11113/mjfas.v15n2.1075
[20] A. Kurt, P. Y1lmaz, Thermal decomposition kinetics of benzofuran derived polymer/organosilicate nanocomposites, Kuwait J. Sci. 43, 172-184 (2016).

[21] N. Ding, W. Sun, Y. Lin, Z. Shen. Synthesis and magnetic properties of complexes of a conjugated hyperbranched polymer containing bithiazole rings, Chinese J. Polym. Sci., 30, 759-769 (2012). DOI: $10.1007 / \mathrm{s} 10118-012-1162-\mathrm{y}$

[22] L. Li, C. Guan, A. Zhang, D. Chen, Z. Qing, Thermal stabilities and the thermaldegradation kinetics of polyimides. Polym. Degrad. Stabil., 84, 369-373 (2004). DOI: doi.org/10.1016/j.polymdegradstab.2003.11.007

[23] A. Kurt, Thermal decomposition kinetics of poly(nButMA-b-St) diblock copolymer synthesized by ATRP, J. Appl. Polym. Sci., 114, 624-629 (2009). DOI: 10.1002/app.30576

[24] X. L. Meng, Y. D. Huang, H. Yu, Z. S. Lv, Thermal degradation kinetics of polyimide containing2,6benzobisoxazole units. Polym. Degrad. Stabil., 92, 962967 (2007).

DOI: 10.1016/j.polymdegradstab.2007.03.005

[25] A. Kurt, M. Koca, Blending of poly(ethyl methacrylate) with poly(2-hydroxy-3-phenoxypropylmethacrylate): Thermal and optical properties. Arab. J. Sci. Eng., 39, 5413-5420 (2014). DOI: 10.1007/s13369-014-1103-x

[26] S. Vyazovkin, Thermal analysis, Anal. Chem. 78, 38753886 (2006), DOI: 10.1021/ac0605546.

[27] S. Ma, J. O. Hill, S. Heng, A kinetic-analysis of the pyrolysis of some Australian coals by nonisothermal thermogravimetry, J. Therm. Anal. 37, 1161-1177 (1991). DOI: $10.1007 / \mathrm{BF} 01913852$

[28] Z. D. Zivkovic, J. Sestak, Kinetics and mechanism of the oxidation of molybdenum sulphide, J. Therm. Anal. Calorim. 53, 263-267 (1998). DOI: 10.1023/A:1010108813595.

[29] F. Fraga, E. R. Nunez, Activation energies for the epoxy system BADGE $\mathrm{n}=0 / \mathrm{m}$-XDA obtained using data from thermogravimetric analysis. J. Appl. Polym. Sci., 80, 776-782 (2001).

DOI: 10.1002/1097-4628(20010502)80:5<776::AIDAPP1154>3.0.CO;2-8 
